\title{
PENDAPATAN ASLI DAERAH DAN DANA ALOKASI UMUM TERHADAP ANGGARAN BELANJA MODAL DI PROVINSI SULAWESI UTARA
}

\author{
Sandi Hasudungan Pasaribu \\ Jantje Tinangon
}

sandihasudungan@gmail.com

\begin{abstract}
The local government allocated funds in the form of capital expenditure in the budget to increase fixed assets. Capital expenditure allocation is based on local needs for facilities and infrastructure, both for the smooth implementation of the tasks for the government and public facilities. Therefore, in an effort to improve the quality of public services, local government should change the composition of spending. During this shopping areas more used to spending relatively less productive routine.

This study carried out in North Sulawesi Provincial Government by taking the data used for the study include data on local revenues, general allocation funds, and capital expenditure obtained from the Finance and Assets Management Agency of North Sulawesi Province.

The purpose of this study was to determine how much influence of local revenues and a general allocation of funds towards capital expenditure budget in North Sulawesi.

The analytical method used is quantitative descriptive analysis method that describes the position of research variables studied and the effect of one variable with other variables. Data analysis techniques to test the hypothesis performed using multiple linear regression analysis were processed through SPSS.

Based on the results simultaneously (test $F$ ) indicates that the variable revenue $(X 1)$, and the general allocation fund (X2) significantly affects the capital expenditure budget in North Sulawesi. While for the results of research partially ( $t$ test) showed that variabels local revenues and a general allocation fund a significant effect on capital expenditure in North Sulawesi.
\end{abstract}

\section{Keywords: Locally-Generated Revenue, General Allocation Fund, Capital Expenditure.}

\section{PENDAHULUAN}

\subsection{Latar Belakang}

Otonomi daerah merupakan hak, wewenang, dan kewajiban daerahotonom untuk mengatur dan mengurus sendiri urusan pemerintah dankepentingan masyarakat setempat sesuai dengan peraturan perundang-undangan.Hal tersebut sesuai dengan ketentuan umum di UU OtonomiDaerah No.32 tahun 2004 tentang Pemerintah Daerah yang telahmenggantikan UU No. 22 tahun 1999. Pelaksanaan kebijakan pemerintahIndonesia tentang Otonomi Daerah, dimulai secara efektif pada tanggal 1Januari 2001, merupakan kebijakan yang dipandang sangat demokratis danmemenuhi aspek desentralisasi yang sesungguhnya. Desentralisasi sendirimempunyai tujuan untuk lebih meningkatkan kesejahteraan dan pelayanankepada masyarakat, pengembangan kehidupan berdemokrasi, keadilan,pemerataan, dan pemeliharaan hubungan yang serasi antara pusat dan daerahdan antar daerah.

Dengan ditetapkannya UU No. 32 Tahun 2004, pemerintah di daerah mendapat kewenangan "riil" yang lebih besar dalam mengatur dirinya sendiri.Hal ini menimbulkan peningkatan tanggungjawab penyelenggaraan pemerintahan (penyediaan barang publik dan pembangunan ekonomi) di tingkat daerah yang sangat besar, khususnya pada bidang pendidikan yang merupakan unsur esensial dalam pembangunan daerah dan telah menjadi salah satu bagian utama kebutuhan penduduk. Namun, kemampuan daerah untuk mempertahankan dan meningkatkan penyelenggaraan pendidikan tersebut dapat dikatakan sangat terbatas, mengingat peranan pendapatan asli daerah masih rendah dalam penerimaan APBD daerah kabupaten/kota dan kesiapan sumber daya manusia (SDM) serta kemampuan manajemen sektor pendidikan di tingkat daerah masih sangat terbatas. 
Namun Tujuan perubahan sistem dari sentralistik top-down menjadi desentralistik bottom-up tidak selamanya berdampak baik. Bahkan banyak permasalahan baru yang timbul. Permasalahan-permasalahan tersebut dapat diuraikan sebagai berikut:

1. Pemerintah daerah masih belum dapat melepaskan diri dari ketergantungan terhadap pemerintah pusat. Desentralisasi yang menghasilkan otonomi daerah ini tidak sepenuhnya dapat dijalankan oleh seluruh daerah di Indonesia. Kota-kota besar yang telah mendapatkan keuntungan pembangunan sejak orde lama dan orde baru mungkin dapat mengikuti proses otonomi. Namun tidak sama halnya dengan daerah-daerah terpencil atau daerah yang lokasinya jauh dari pusat. Pejabat daerah yang pada masa sebelumnya tidak pernah menerima kepercayaan dari pemerintah pusat untuk mengelola wilayahnya sendiri, dan tiba-tiba setelah adanya otonomi daerah mendapatkan wewenang tersebut, pasti tidak dapat serta merta meengelola wilayahnya. Apalagi pengelolaan kekayaan alam di daerahnya harus dengan dana sendiri. Oleh karena itu, banyak daerah-daerah yang masih tergantung terhadap pusat terutama untuk permasalahan anggaran atau dana pembangunan.

2. Semakin tingginya penarikan biaya kepada masyarakat. Berdasarkan Undang-undang Nomor 33 Tahun 2004 tentang Perimbangan Keuangan Pusat dengan Daerah, sumber penerimaan daerah terdiri dari 2, yaitu pendapatan daerah dan pembiayaan daerah. Pendapatan daerah bersumber dari pendapatan asli daerah (PAD), dana perimbangan, lain-lain pendapatan. Sedangkan pembiayaan bersumber dari sisa lebih perhitungan anggaran daerah, penerimaan pinjaman daerah, dana cadangan daerah, dan hasil penjualan kekayaan daerah yang dipisahkan. Adapun sumber PAD adalah pajak daerah, retribusi daerah, hasil pengelolaan kekayaan daerah yang dipisahkan, hasil penjualan kekayaan daerah yang tidak dipisahkan, jasa giro, pendapatan bunga, keuntungan selisih nilai tukar rupiah terhadap mata uang asing, serta komisi, potongan, ataupun bentuk lain sebagai akibat dari penjualan dan/atau pengadaan barang dan/atau jasa oleh daerah. Ditilik dari penjelasan tersebut, maka seharusnya PAD terbesar berasal dari hasil pengelolaan dan penjualan kekayaan daerah serta penjualan ataupun pengadaan barang dan jasa daerah sebagai bentuk otonomi daerah. Namun pada kenyataannya, PAD di kebanyakan daerah bersumber dari pajak dan retribusi daerah.

3. Kasus-kasus korupsi oleh pejabat-pejabat pemerintah daerah. Adanya sistem desentralisasi ini bukan berarti bebas dari permasalahan korupsi. Bahkan otonomi daerah mampu menciptakan koruptorkoruptor kecil dari daerah. Berdasarkan laporan dari Indonesia Corruption Watch (ICW), pada tahun 2004 terjadi 432 kasus korupsi di Indonesia dengan berbagai macam aktor, modus, dan kerugian negara. Adapun 83 kasus melibatkan kepala daerah, dan 124 kasus melibatkan anggota DPRD.

Anggaran daerah merupakan rencana keuangan yang menjadi dasar dalam pelaksanaan pelayanan publik. Di Indonesia, dokumen anggaran derah disebut APBD, baik untuk provinsi maupun kabupaten dan kota. Proses penyusunan anggaran pasca UU No.2 tahun 1999 dan UU No.32 tahun 2004, melibatkan dua pihak eksekutif dan legislatif, masing-masing melalui sebuah tim atau panitia anggaran. Adapun eksekutif sebagai pelaksana operasionalisasi daerah berkewajiban membuat draft/rancangan APBD, yang hanya bias di implementasikan kalau sudah disahkan oleh DPRD dalam proses ratifikasi anggaran.

Penyusunan APBD diawali dengan membuat kesepakatan antara eksekutif dan legislatif tentang Kebijakan Umum APBD dan Prioritas \& Plafon Anggaran yang akan menjadi pedoman untuk penyusunan anggaran pendapatan dan anggaran belanja. Eksekutif membuat rancangan APBD sesuai dengan Kebijakan Umum APBD dan Prioritas \& Plafon Anggaran yang kemudian diserahkan kepada legislative untuk dipelajari dan dibahas bersama-sama sebelum ditetapkan sebagai Peraturan Daerah (Perda).Dalam perspektif keagenan, hal ini merupakan bentuk kontrak (incomplete contract), yang menjadi alat bagi legislatif untuk mengawasi pelaksanaan anggaran oleh eksekutif.

Berlakunya UU No. 25 tahun 1999 dan UU No. 33 tahun 2004 tentang Perimbangan Keuangan Pusat dan Daerah, membawa perubahan mendasar pada sistem dan mekanisme pengelolaan pemerintahan daerah. UU ini menegaskan bahwa untuk pelaksanaan kewenangan Pemerintah Daerah, Pemerintah Pusat akan mentransferkan dana perimbangan kepada Pemda. Dana Perimbangan tersebut terdiri dari Dana Alokasi Umum, Dana Alokasi Khusus, dan bagian daerah dari bagi hasil pajak pusat.Disamping itu, Pemerintah Daerah juga memiliki simber pendanaan sendiri berupa PAD, pinjaman daerah, maupun lainlain penerimaan daerah yang sah. Kebijakan penggunaan semua dana tersebut diserahkan kepada Pemda (Prakosa, 2004). Namun pada praktiknya, transfer dari pemerintah pusat merupakan sumber pendanaan 
utama Pemda untuk membiayai operasi utamanya sehari-hari, yang oleh Pemda "dilaporkan" di perhitungkan APBD.

Pemerintah daerah mengalokasikan dana dalam bentuk anggaran belanja modal dalam APBD untuk menambah aset tetap. Alokasi belanja modal ini didasarkan pada kebutuhan daerah akan sarana dan prasarana, baik untuk kelancaran pelaksanaan tugas pemerintahan maupun untuk fasilitas publik. Oleh karena itu, dalam upaya meningkatkan kualitas pelayanan publik, pemerintah daerah seharusnya mengubah komposisi belanjanya. Selama ini belanja daerah lebih banyak digunakan untuk belanja rutin yang relatif kurang produktif. Saragih (2003) menyatakan bahwa pemanfaatan belanja hendaknya dialokasikan untuk hal-hal produktif, misal untuk melakukan aktivitas pembangunan.

Berdasarkan penjelasan diatas, penulis tertarik untuk melakukan penelitian mengenai : "Pengaruh Pendapatan Asli Daerah, dan Dana Alokasi Umum terhadap Anggaran Belanja Modal di Provinsi Sulawesi Utara".

\subsection{Perumusan Masalah}

Berdasarkan uraian latar belakang yang dikemukakan di atas, maka yang menjadimasalah pokok dalam penelitian ini dapat dirumuskan sebagai berikut:

1. Apakah pendapatan asli daerah berpengaruh terhadap anggaran belanja modal di Provinsi Sulawesi Utara?

2. Apakah dana alokasi umum berpengaruh terhadap anggaran belanja modal di Provinsi Sulawesi Utara?

3. Apakah secara bersama-sama pendapatan asli daerah dan dana alokasi umum berpengaruh terhadap anggaran belanja modal di Provinsi Sulawesi Utara?

\subsection{Tujuan Penelitian}

Berdasarkan rumusan masalah yang dikemukakan di atas, maka tujuan penelitianini adalah untuk :

1. Mengetahui pengaruh pendapatan asli daerahterhadap anggaran belanja modal di Provinsi Sulawesi Utara?

2. Mengetahui pengaruh dana alokasi umum terhadap anggaran belanja modal di Provinsi Sulawesi Utara?

3. Mengetahui secara bersama-sama pengaruh pendapatan asli daerah dan dana alokasi umum terhadap anggaran belanja modal di Provinsi Sulawesei Utara?

\subsection{Manfaat Penelitian} adalah:

Apabila tujuan penelitian ini dapat dipenuhi, maka manfaat yang diharapkan daripenelitian ini

1 Bagi peneliti, untuk menambah pengetahuan dan wawasan peneliti sehubungan dengan pengaruh pendapatan asli daerah dan dana alokasi umum terhadap anggaran belanja modal di Provinsi Sulawesi Utara.

2 Bagi pemerintah daerah, memberikan masukan dalam hal penyusunan kebijakan dimasa yang akan datang dalam hal pengalokasian anggaran belanja modal yang terdapat di dalam APBD.

\subsection{Tinjauan Pustaka}

Darwanto dan Sari (2007), melakukan penelitian yang berjudul "pengaruh pertumbuhan ekonomi, pendapatan asli daerah, dan dana alokasi umum terhadap pengalokasian anggaran belanja modal, kasus: di ProvinsiJawa dan Bali" menyatakan bahwa adanya pertumbuhan ekonomi (PDRB) memiliki korelasi positif namun tidak signifikan terhadap belanja modal, artinya pertumbuhan ekonomi kurang memiliki pengaruh yang nyata terhadap belanja modal. Sedangkan pendapatan asli daerah (PAD)memiliki korelasi positif dan signifikan terhadap belanja modal, artinya PAD memiliki pengaruh yang nyata terhadap belanja modal dan hubungannya positif. Begitu juga dengan dana alokasi umum (DAU) memiliki korelasi positif yang signifikan terhadap belanja modal, artinya DAU memiliki korelasi (hubungan) yang nyata dengan belanja modal dan hubungannya negatif.Kesamaan antara penelitian sebelumnya dengan yang ini, dimana terletak pada variabelpendapatan asli daerah, dan dana alokasi umum dan menggunakan metode analisis yang sama. Sedangkan perbedaannya terletak pada pertumbuhan ekonomi dan objek penelitian sebelumnnya dengan yang saat ini yaitupada Provinsi Jawa dan Bali sedangkan penelitian ini di Provinsi Sulawesi Utara.

Syafitri (2009), melakukan penelitian yang berjudul "pengaruh pertumbuhan ekonomi, pendapatan asli daerah, dan dana alokasi umum terhadap pengalokasian anggaran belanja modal", kasus: Provinsi 
Sumatra Utara tahun 2006-2008. Menyatakan secara parsial bahwa hanya pendapatan asli daerah (PAD) yang mempunyai pengaruh signifikan positif terhadap belanja modal. Sedangkan PDRB dan dana alokasi umum (DAU) tidak berpengaruh signifikan terhadapbelanja modal. Kesamaan dengan penilitian saat ini yaitu menggunakan variabel pendapatan asli daerah, dana alokasi umum, dan belanja modal tetapi yang membedakannya adalah tidak digunakannya variabel pertumbuhan ekonomi dan objek penelitian, dimana penelitian sebelumnya mengambil tempat di Provinsi Sumatra Utara sedangkan penelitian saat ini mengambil tempat di Provinsi Sulawesi Utara.

Fitria (2013), melakukan penelitian yang berjudul "pengaruh pertumbuhan ekonomi, pendapatan asli daerah, dan danaalokasi umum terhadap pengalokasian anggaran belanja modal, studi kasus: pada Kabupaten/Kota di Provinsi Jawa Barat" menyatakan bahwa adanya pertumbuhan ekonomi (PDRB) memiliki korelasi positif dan signifikan terhadap belanja modal, artinya pertumbuhan ekonomi memiliki pengaruh yang nyata terhadap belanja modal. Sedangkan pendapatan asli daerah (PAD)memiliki korelasi positif dan signifikan terhadap belanja modal, artinya PAD memiliki pengaruh yang nyata terhadap belanja modal dan hubungannya positif. Begitu juga dengan dana alokasi umum (DAU) memiliki korelasi positif yang signifikan terhadap belanja modal, artinya DAU memiliki korelasi (hubungan) yang nyata dengan belanja modal dan hubungannya positif.Kesamaan antara penelitian sebelumnya dengan yang saat ini, dimana sama-sama menggunakan pendapatan asli daerah, dan dana alokasi umum dan menggunakan metode analisis yang sama. Sedangkan perbedaannya terletak pada pertumbuhan ekonomi dan objek penelitian yang mana penelitian sebelumnnya mengambil objek di Provinsi Jawa Barat sedangkan penelitian ini di Provinsi Sulawesi Utara.

\subsection{Hipotesis}

Berdasarkan landasan teori di atas, maka hipotesis pada penelitian ini adalah sebagai berikut:

Hipotesis 1: Variabelpendapatan asli daerah $\left(\mathrm{X}_{1}\right)$ berpengaruh secara signifikan terhadap anggaran belanja modal (Y) di Provinsi Sulawesi Utara.

Hipotesis 2: Variabeldana alokasi umum $\left(\mathrm{X}_{2}\right)$ berpengaruh secara signifikan terhadap anggaran belanja modal (Y) di Provinsi Sulawesi Utara.

Hipotesis 3: Variabelpendapatan asli daerah $\left(\mathrm{X}_{1}\right)$ dandana alokasi umum $\left(\mathrm{X}_{2}\right)$ berpengaruh secara signifikan terhadap anggaran belanja modal (Y) di Provinsi Sulawesi Utara.

\subsection{Sistematika Penulisan}

Untuk mempermudah dan memberikan gambaran secara menyeluruhdalam penelitian ini, maka penulis membaginya kedalam lima bab berikut :

\section{BAB I PENDAHULUAN}

Bab ini berisi bagian pendahuluan yang terdiri dari: latar belakangmasalah, perumusan masalah, tujuan penelitian, manfaat penelitian,tinjauan pustaka, hipotesis, serta sistematika penulisan.

\section{BAB II LANDASAN TEORI}

Pada bab ini berisi penjelasan dan pembahasan secara rinci tentang landasan teori meliputi pendapatan asli daerah, dana alokasi umum dan belanja modal .

\section{BAB III METODE PENELITIAN}

Bab ini berisi uraian secara umum mengenai jenis data, sumber data, metode pengumpulan data, definisi operasional dan pengukuran variabel, metode analisis data.

\section{BAB IV HASIL PENELITIAN DAN PEMBAHASAN}

Dalam bab ini berisi tentang uraian secara rinci mengenai langkah-langkah analisis data dan hasilnya serta pembahasan hasil yangdiperoleh.

\section{BAB V KESIMPULAN DAN SARAN}

Dalam bab terakhir ini berisi kesimpulan penelitian, keterbatasan,dan saran-saranyang perlu disampaikan.

\section{LANDASAN TEORI}

\subsection{Anggaran Pemerintah Daerah}

Anggaran pemerintah daerah adalah alat bagi pemerintah untuk mengarahkan pembangunan sosial dalam menjamin kesinambungan serta meningkatkan kualitas hidup masyarakat.Anggaran sektor publik memuat berbagai pernyataan mengenai estimasi kinerja yang hendak dicapai selama periode waktu 
tertentu yang dinyatakan dalam ukuran finansial.Pembentukan anggaran sektor publik kerap kali melibatkan unsur politik dan sejenisnya.

Anggaran pada pemerintah daerah memiliki fungsi yang sama dengan anggaran pada perusahaan komersil, yaitu sebagai pernyataan mengenai rencana kerja yang akan dilakukan pada periode waktu tertentu. Anggaran pemerintah daerah menurut Mardiasmo $(2004 ; 62)$ yaitu merupakan suatu rencana kegiatan yang dipresentasikan dalam bentuk rencana perolehan pendapatan dan belanja dalam satuan moneter."

\subsubsection{Jenis-jenis Anggaran Pemerintah daerah}

Ada beberapa pendekatan dalam penyusunan anggaran. Seperti yang dikemukakan oleh Mardiasmo (2004; 76-83)bahwa pendekatan dalam penyusunan anggaran sebagai berikut :

1. Anggaran Tradisional

Anggaran tradisional memiliki dua ciri utama yaitu cara penyusunan anggaran yang didasarkan atas pendekatan incrementalism dan struktur susunan anggaran yang bersifat line-item.

a. Line Item Budgeting

b. Incremential Budgeting

2. New Public Management

New Publik Management berfokus pada manajemen sektor publik yang berorientasi pada kinerja bukan berorientasi kebijakan new public managemen menimbulkan beberapa konsekuensi bagi pemerintah. Diantaranya adalah tuntutan-tuntutan untuk melakukan efisiensi, penangkasan biaya dan kompetensi tender.

a. Anggaran kinerja (Ferporment Budgeting)

b. Zero Based Budgetting (ZBB)

c. Planning, Programming and Budgeting System (PPBS)

\subsubsection{Proses Penyusunan Anggaran Pemerintah Daerah}

Proses penyusunan anggaran pada sektor publik cukup rumit karena dalam proses penganggarannya mengandung nuansa politisi. Menurut Mardiasmo (2004;61),dikemukakan bahwa penganggaran pemerintah daerah adalah sebagai suatu proses penentuan jumlah alokasi dana untuk tiaptiap program dan aktivitas dalam satuan moneter.

Proses penyusunan anggaran mempunyai empat tujuan seperti yang dikemukakan oleh Mardiasmo (2004;61)adalah sebagai berikut :

a. Membantu pemerintah mencapai tujuan fiskal dan meningkatkan koordinasi antar bagian dalam lingkunga pemerintah.

b. Membantu menciptakan efisiensi dan keadilan dalam menyediakan barang dan jasa publik melalui proses pemrioritasan.

c. Memungkinkan bagi pemerintah untuk memenuhi prioritas belanja.

d. Meningkatkan transparansi dan pertanggungjawaban pemerintah kepada DPR/DPRD dan masyarakat luas."

\subsection{Anggaran Pendapatan dan Belanja Daerah (APBD)}

Anggaran pendapatan dan belanja daerah (APBD) pada hakekatnya merupakan salah satu instrumen kebijakan yang dipakai sebagai alat untuk meningkatkan pelayanan umum dan kesejahteraan masyarkat di daerah. Menurut Halim (2004:15), Anggaran pendapatan daerah (APBD) adalah suatu Anggaran Daerah, yang memiliki unsur-unsur sebagai berikut : rencana kegiatan suatu daerah, beserta uraiannya secara rinci; adanya sumber penerimaan yang merupakan target minimal untuk menutupi biaya-biaya sehubungan dengan aktivitas-aktivitas terebut, dan adanya biaya-biaya yang merupakan batas maksimal pengeluaran-pengeluaran yang akan dilaksanakan; jenis kegiatan dan proyek yang dituangkan dalam bentuk angka; periode anggaran, yaitu biasanya 1 (satu) tahun.

APBD harus memuat sasaran yang diaharapkan menurut fungsi belanja, standar pelayanan yang diharapkan dan perkiraan biaya satuan komponen kegiatan yang bersangkutan, serta bagian pendapatan APBD yang digunakan untuk membiayai belanja administrasi umum, belanja operasi dan pemelihraan dan belanja modal/investasi.

Unsur-unsur APBD menurut Halim (2004 : 15-16) adalah sebagai berikut:

1. Rencana kegiatan suatu daerah, beserta uraiannya secara rinci. 
2. Adanya sumber penerimaan yang merupakan target minimal untuk menutupi biaya-biaya sehubungan dengan aktivitas tersebut, dan adanya biaya-biaya yang merupakan batas maksimal pengeluaran-pengeluaran yang akan dilaksanakan.

3. Jenis kegiatan dan proyek yang dituangkan dalam bentuk angka.

4. Periode anggaran yang biasanya 1 (satu) tahun.

\subsubsection{Struktur APBD}

Struktur APBD yang terbaru adalah berdasarkan Peraturan Menteri Dalam Negeri nomor 13 tahun 2006 tentang pedoman pengelolaan keuangan daerah. Adapun bentuk dan susunan APBD yang didasarkan pada Permendagri 13/2006 pasal 22 ayat (1) terdiri atas 3 bagian, yaitu : "pendapatan daerah, belanja daerah, dan pembiayaan daerah." Pendapatan daerah sebagaimana dimaksud dalam pasal 22 ayat (1) dikelompokkan atas pendapatan asli daerah, dana perimbangan, dan lain-lain pendapatan daerah yang sah. Belanja menurut kelompok belanja terdiri dari belanja tidak langsung dan belanja langsung.Pembiayaan daerah terdiri dari penerimaan pembiayaan dan pengeluaran pembiayaan. Penerimaan pembiayaan mencakup sisa lebih perhitungan anggaran tahun anggaran sebelumnya (SilPA), pencairan dana cadangan, hasil penjualan kekayaan daerah yang dipisahkan, penerimaan pinjaman daerah, penerimaan kembali pemberian pinjaman, dan penerimaan piutang daerah. Pengeluarn pembiayaan mencakup pembentukan dana cadangan, penyertan modal (invetasi) pemerintah daerah, pembayaran pokok utang, dan pemberian pinjaman daerah. (permendagri 13/2006). Oleh karena ini mengunakan laporan APBD yang memakai format Keputusan Menteri Dalam Negeri No.29 Tahun 2002, maka APBD yang berdasarkan format tersebut terdiri atas 3 bagian, yaitu : "pendapatan, belanja, dan pembiayaan."

Pendapatan dibagi menjadi 3 kategori yaitu Pendapatan Asli Daerah (PAD), Dana Perimbangan, dan lain-lain pendapatan daerah yang sah.Belanja digolongkan menjadi 4 yakni belanja aparatur daerah, belanja pelayanan publik, belanja bagi hasil dan bantuan keuangan, dan belanja tak tersangka.Belanja aparatur daerah diklasifikasikan menjadi 3 kategori yaitu belanja administrasi umum, belanja operasi dan pemeliharaan, dan belanja modal/pembangunan.Belanja pelayanan publik dikelompokan menjadi 3 yakni belanja administrasi umum, belanja operasi dan pemeliharaan, dan belanja modal. Pembiayaan dikelompokkan menurut sumber-sumber pembiayaan yaitu : sumber penerimaan daerah dan sumber pengeluaran daerah. Sumber pembiayaan berupa penerimaan daerah adalah : sisa lebih anggaran tahun lalu, penerimaan pinjaman obligasi, hasil penjualan asset daerah yang dipisahkan dan transfer dana cadangan. Sumber pembiayaan berupa pengeluaran daerah terdiri atas : pembayaran utang pokok yang telah jatuh tempo, penyertaan modal, transfer ke dana cadangan, dan sisa lebh anggaran tahun sekarang. (Halim 2004:18)

\subsection{Pendapatan Asli Daerah (PAD)}

Pengertian pendapatan asli daerah berdasarkan Undang-Undang No. 33 tahun 2004 tentang perimbangan keuangan antara pusat dan daerah pasal 1 angka 18 bahwa : pendapatan asli daerah, selanjunya disebut PAD adalah pendapatan yang diperoleh daerah yang dipungut berdasarkan peraturan daerah sesuai dengan perundang-undangan.

Adapun kelompok pendapatan asli daerah yang dipisahkan menjadi empat jenis pendapatan, diantaranya:

1. Pajak daerah

2. Retribusi daerah

3. Pengelolaan kekayaan daerah yang dipisahkan

4. Lain-lain pendapatan yang sah

\subsubsection{Hubungan PAD dengan Belanja Modal}

Selama ini PAD memiliki peran untuk membiayai pelaksanaan otonomi daerah guna mencapai tujuan utama penyelenggaraan otonomi daerah yang ingin meningkatkan pelayanan publik dan memajukan perekonomian daerah (Mardiasmo, 2004:46). Bermula dari keinginan untuk mewujudkan harapan tersebut, Pemda melakukan berbagai cara dalam meningkatkan pelayanan publik, yang salah satunya dilakukan dengan melakukan belanja untuk kepentingan investasi yang direalisasikan melalui belanja modal, jika semakin tinggi PAD maka pengeluaran pemerintah atas Belanja Modal pun akan semakin tinggi. Hal ini sesuai dengan PP No 58 tahun 2005 tentang pengelolaan keuangan daerah yang menyatakan bahwa APBD disusun sesuai dengan kebutuhan penyelenggaraan pemerintah dan 
kemampuan pendapatan daerah. Artinya, disetiap penyusunan APBD, jika Pemerintah Daerah akan mengalokasikan Belanja Modal maka harus benar-benar disesuaikan dengan kebutuhan daerah dengan mempertimbangkan PAD yang diterima. Besar kecilnya belanja modal akan ditentukan dari besar kecilnya PAD. Sehingga jika Pemda ingin meningkatkan pelayanan publik dan kesejahteraan masyarakat dengan jalan meningkatkan belanja modal, maka Pemda harus menggali PAD yang sebesar-besarnya.

\subsection{Dana Alokasi Umum (DAU)}

Menurut Peraturan Pemerintah Nomor 55 Tahun 2005 tentang dana perimbangan atau Dana Alokasi Umum, bahwa : "Dana Alokasi Umum (DAU) adalah dana yang berasal dari APBN yang dialokasikan dengan tujuan pemerataan keuangan antar daerah untuk membiayai kebutuhan pengeluaran dalam rangka pelaksanaan desentralisasi”.

Secara definisi DAU dapat diartikan sebagai berikut:

1. Salah satu komponen dari dana perimbangan pada APBN, yang pengalokasiannya didasarkan atas konsep kesenjangan fiskal yaitu selisih antara kebutuhan fiscal dengan kapital fiskal.

2. Instrumen untuk mengatasi horizontal balance yang dialokasikan dengan tujuan pemerataan kemampuan keuangan antar daerah dan penggunaannya ditetapkan sepenuhnya oleh daerah.

3. Equalization grantberfungsi untuk menetralisasi ketimpangan kemampuan keuangan dengan adanya PAD, Bagi Hasil Pajak dan bagi hasil SDA yang diperoleh daerah (Sigit, 2003; Kuncoro, 2004:31).

\subsubsection{Hubungan DAU dengan Belanja Modal}

Hubungan antara DAU dengan Belanja Modal ini dapat dipahami mengingat bahwa pelaksanaan otonomi daerah yang bertujuan untuk meningkatkan pelayanan publik yang direalisasikan melalui belanja modal yang juga ikut dibiayai oleh DAU tersebut. Bahkan Abdullah dan Halim (2006:26) menyatakan bahwa pendapatan dari pemerintah pusat berupa dana perimbangan di pemerintah daerah di Indonesia merupakan sumber pendapatan utama dalam APBD. Sayangnya kontribusi DAU terhadap Belanja Modal belum efektif sehingga masih banyak daerah yang belum merata pembangunannya, juga masih kurangnya pelayanan publik sehingga kesejahteraan masyarakat pun belum efektif (masih banyaknya masyarakat dibawah garis kemiskinan, belum meratanya fasilitas pendidikan dan kesehatan, sektor usaha kecil masih terabaikan contoh PKL).

\subsection{Belanja Modal}

Berdasarkan Keputusan Menteri Dalam Negeri No. 29 Tahun 2002, belanja modal dibagi menjadi:

a. Belanja publik, yaitu belanja yang manfaatnya dapat dinikmati secara langsung oleh masyarakat umum.

b. Belanja aparatur, yaitu belanja yang manfaatnya tidak secara langsung dinikmati oleh masyarakat, tetapi dirasakan secara langsung oleh aparatur.

Belanja Modal dapat diaktegorikan dalam 5 (lima) kategori utama:

a) Belanja Modal Tanah

b) Belanja Modal Peralatan dan Mesin

c) Belanja Modal Gedung dan Bangunan

d) Belanja Modal Jalan, Irigasi dan Jaringan

e) Belanja Modal Fisik Lainnya

\section{METODE PENELITIAN}

\subsection{Jenis Data}

Jenis data yang digunakan dalam penelitian ini adalah data kuantitatif yaitu data yang dapat diukur dengan angka.

\subsection{Sumber Data}

Sumberdata yang digunakan oleh peneliti adalah data sekunder yang bersumber dari laporanRealisasi APBD Pemda di Provinsi Sulawesi Utara, yakni dataPAD, DAU, dan Belanja Modal yang diperoleh dari situs DirjenPerimbangan Keuangan Daerah melalui internet dan BPKAD. Adapun data yang digunakan adalah data time series dengan periode waktu daritahun 2004 sampai dengan tahun 2014.

\subsection{Metode Pengumpulan Data}

Untuk memperoleh data yang diperlukan dalam proses penganalisaan maka penulis menggunakan metode sebagai berikut: 
1. Studi kepustakaan,

2. Penelitian lapangan

\subsection{Definisi Operasional dan Pengukuran Variabel}

Dalam penelitian ini ada beberapa variabel yang diukur antara lain :

1. Pendapatan Asli Daerah $\left(\mathrm{X}_{1}\right)$ yaitu merupakan semua penerimaan daerah yang berasal dari sumber ekonomi asli daerah yang dilihat dari laporan realisasi APBD pada bagian pendapatan. Pengukuran variabel ini menggunakan nilai nominal dari jumlah penerimaan PAD dalam setahun.

2. Dana Alokasi Umum $\left(\mathrm{X}_{2}\right)$ yaitu dana yang berasal dari APBN yang dialokasikan dengan tujuan pemerataan kemampuan keuangan antar daerah untuk membiayai kebutuhan pengeluarannya dalam rangka desentralisasi, yang dapat dilihat dari laporan realisasi APBD pada bagian Perimbangan. Pengukuran variabel ini menggunakan nilai nominal dari jumlah DAU dalam setahun.

3. Belanja Modal (Y) yaitu belanja pemerintah daerah yang manfaatnya melebihi satu tahun anggaran dan akan menambah aset atau kekayaan daerah dan selanjutnya akan menambah belanja yang bersifat rutin seperti biaya pemeliharaan pada kelompok belanja administrasi umum, yang dapat dilihat dalam laporan realisasi APBD pada bagian belanja aparatur daerah dan pelayanan publik. Pengukuran variabel ini menggunakan nilai nominal dari jumlah anggaran belanja modal dalam setahun.

\subsection{Metode Analisis Data}

Sebelum melakukan pengujian dengan regresi linear berganda, terlebih dahulu dilakukan Uji Asumsi Klasik,antara lain :Uji Normalitas, Uji Autokorelasi, Uji Heterokedastisitas, Uji Multikolinearitas, Analisis Regresi Linear Berganda, Koefisien Korelasi (R)\& Determinasi $\left(\mathrm{R}^{2}\right)$ dan Uji Hipotesis.

\section{HASIL PENELITIAN DAN PEMBAHASAN}

4.1 Hasil Analisis

Uji Asumsi Klasik

Uji Normalitas

Tabel 4.1 Test of Normality

\begin{tabular}{cc}
\hline & Unstandardized Residual \\
\hline $\mathrm{df}$ & 11 \\
Kolmogorov-Smirnov $^{\mathrm{a}}$ & .166 \\
Asymp. Sig. (2-tailed) & $.200^{\mathrm{a}}$ \\
\hline Sumber : Hasil Olah Data SPSS, & 2014
\end{tabular}

Dari Tabel 4.1 diatas, terlihat bahwa nilai Sig. (2-tailed) dalam One-Sample Kolmogorov-Smirnov Test adalah 0,200>0,05, maka dapat disimpulkan bahwa residual error data terdistribusi memenuhi asumsi normalitas.

\section{Uji Autokorelasi}

Tabel 4.2 Model Summary ${ }^{b}$

\begin{tabular}{cc}
\hline Model & Durbin-Watson \\
\hline 1 & 2.098 \\
\hline Sumber : Hasil Olah Data SPSS, 2014
\end{tabular}

Berdasarkan pada tabel 4.2 diatas,nilai DW yang dihasilkan adalah sebesar 2,098, maka dapat disimpulkan bahwa data penelitian tidak terjadi autokorelasi dalam regresi.

Tabel 4.3 Coefficients ${ }^{\mathrm{a}}$

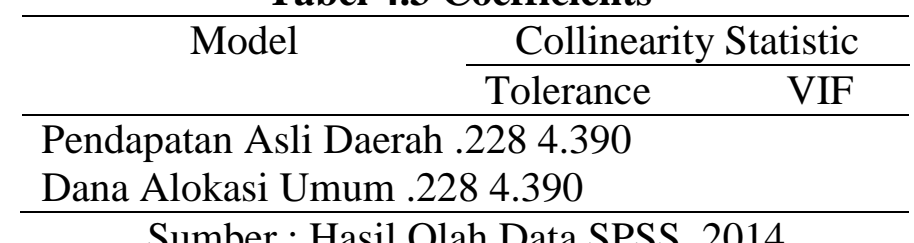

Sumber : Hasil Olah Data SPSS, 2014 
Dengan melihat nilaiVIF pada tabel 4.3 diatas, setiap variabel independen dibawah 10, yaitu pendapatan asli daerah sebesar 4,390, dan dana alokasi umum sebesar 4,390, maka dapat disimpulkan bahwa variabel penelitian tidak terjadi multikolinearitas.

\section{Uji Heteroskedastisitas}

\begin{tabular}{ccc}
\multicolumn{3}{c}{ Tabel 4.4 Coefficients $^{\mathbf{a}}$} \\
\hline \multicolumn{2}{c}{ Model } & Sig. \\
\hline $1 \quad$ (Constant) .069 \\
& Pendapatan Asli Daerah & .929 \\
& Dana Alokasi Umum & .786 \\
\hline
\end{tabular}

Sumber : Hasil Olah Data SPSS, 2014

Berdasarkan tabel 4.4 diatas, nilai signifikansi untuk masing-masing variabel independen terhadap nilai absolute residual berada di atas 0,05 , sehingga dapat disimpulkan tidak terdapat gejala heteroskedastisitas pada data penelitian ini.

Analisis Regresi Linear Berganda

Tabel 4.5 Coefficients ${ }^{\mathrm{a}}$

\begin{tabular}{llccc}
\hline Model & & B & t & Sig. \\
\hline 1 & (Constant) & $7.801 \mathrm{E} 10$ & 2.766 & .024 \\
& Pendapatan Asli Daerah & .579 & 6.045 & .000 \\
& Dana Alokasi Umum & .370 & 3.605 & .007 \\
\hline \multicolumn{2}{r}{ Sumber : Hasil Olah Data SPSS, 2014 }
\end{tabular}

Dari Tabel 4.5 di atas, maka dapat diketahui bahwa model regresi yang diperoleh adalah :

$$
\begin{aligned}
& Y=\alpha+\beta_{1} X_{1}+\beta_{2} X_{2}+e \\
& Y=7.801 E 10+0.579 X_{1}+0_{0.370} X_{2}
\end{aligned}
$$

\begin{tabular}{|c|c|c|}
\hline \multicolumn{3}{|c|}{ Tabel 4.6 Model Summary } \\
\hline Model & R Square & Adjusted Square \\
\hline 1 & .932 & 914 \\
\hline
\end{tabular}

\section{Koefisien Korelasi dan Determinasi}

Berdasarkan tabel 4.6 diatas, dapat dilihat perbandingan hasil dari uji koefisien determinasi, dimana jika dilihat dari nilai adjusted $\mathrm{R}$ squarenya, hasil uji dengan variabel moderasi lebih baik daripada hasil uji tanpa variabel moderasi, hal tersebut dapat kita lihat dari perbandingan nilai adjusted $\mathrm{R}$ square.

Untuk mengetahui seberapa besar pengaruh variabel independen (pendapatan asli daerah, dan dana alokasi umum) terhadap variabel dependennya (anggaran belanja modal) digunakan Nilai adjusted $\mathrm{R}^{2}$ tanpa variabel moderasi yaitu sebesar 0,914 , memiliki arti bahwa 91,4\% perubahan anggaran belanja modal dapat dijelaskan oleh variabel pendapatan asli daerah dan dana alokasi umum. Sedangkan sisanya $8,6 \%$ dipengaruhi oleh variabel lain diluar model.

\subsubsection{Uji Hipotesis} Hasil Uji F

Tabel 4.7 ANOVA ${ }^{b}$

\begin{tabular}{lllccr}
\hline Model & & Sum of Square & df & F & Sig. \\
\hline 1 & Regression & $1.039 \mathrm{E} 23$ & 2 & 54.439 & $.000^{\mathrm{a}}$ \\
& Residual & $7.637 \mathrm{E} 21$ & 8 & & \\
& Total & $1.116 \mathrm{E} 23$ & 10 & & \\
\hline
\end{tabular}

Sumber : Hasil Olah Data SPSS, 2014 
Dari tabel 4.7 di atas, dapat dilihat pada signifikan $0,000<0,05$, maka dapat dinyatakan bahwa secara simultan, variabel pendapatan asli daerah dan dana alokasi umum berpengaruh secara signifikan terhadap anggaran belanja modal.

\section{Hasil uji t}

Tabel 4.8 Coefficients ${ }^{\text {a }}$

\begin{tabular}{lcccc}
\hline \multicolumn{1}{l}{ Model } & \multicolumn{2}{c}{ B } & \multicolumn{1}{c}{ t } & Sig. \\
\hline 1 & (Constant) & $7.801 \mathrm{E} 10$ & 2.766 & .024 \\
& Pendapatan Asli Daerah & .579 & 6.045 & .000 \\
& Dana Alokasi Umum & .370 & 3.605 & .007 \\
\hline
\end{tabular}

Sumber : Hasil Olah Data SPSS, 2014

Dari tabel 4.8 dapat dilihat bahwa nilai signifikansi pendapatan asli daerahadalah $0,000<0,05$ hal ini menunjukan Ha diterima sehingga pendapatan asli daerah berpengaruh terhadap anggaran belanja modal.Sedangkan nilai signifikansi dana alokasi umum adalah $0,07<0,05$ menunjukkan Ha diterima sehingga dana alokasi umum berpengaruh terhadap anggaran belanja modal.

\subsection{Pembahasan}

\subsubsection{Pengaruh Pendapatan Asli Daerah terhadap Anggaran Belanja Modal}

Berdasarkan hasil uji t sebelumnya, Hasil analisis menunjukkan bahwa pendapatan asli daerah berpengaruh secara signifikan terhadap anggaran belanja modal ini bisa dilihat dengan tingkat signifikansi $0,000<0,05$, dengan koefisien regresi sebesar positif 0,579 menandakan bahwa apabila pendapatan asli daerah bertambah atau mengalami peningkatan sebesar Rp. 1, maka anggaran belanja modal yang dialokasikan akan ikut bertambah atau mengalami kenaikan sebesar Rp. 0,579 dengan asumsi variabel lainnya tetap atau konstan. Hasil pengujian ini tidak sejalan dengan penelitian yang dilakukan oleh Abdullah (2004) yang membuktikan bahwa tidak terdapat pengaruh belanja modal pada kenaikan pendapatan asli daerah.

Pendapatasn asli daerah merupakan sumber pendapatan penting bagi sebuah daerah dalam memenuhi belanjanya.Pendapatan asli daerah ini sekaligus dapat menunjukan tingkat kemandirian suatu daerah. Semakin banyak pendapatan asli daerah yang didapat semakin memungkinkan daerah tersebut untuk memenuhi kebutuhan belanjanya sendiri tanpa harus tergantung pada Pemerintah Pusat, yag berarti ini menunjukkan bahwa Pemerintah Daerah tersebut telah mampu untuk mandiri, dan begitu juga sebaliknya. Belanja daerah adalah semua pengeluaran Pemerintah Daerah pada suatu periode anggaran.Alokasi belanja daerah terdiri dari belanja tidak langsung dan belanja langsung. Belanja tidak langsung merupakan belanja yang tidak memiliki keterkaitan secara langsung dengan pelaksanaan program dan kegiatan, terdiri dari belanja pegawai, belanja bunga, subsidi, hibah, bantuan sosial, belanja bagi hasil, bantuan keuangan dan belanja tidak terduga. Sedangkan belanja langsung merupakan belanja yang memiliki keterkaitan secara langsung dengan program dan kegiatan yang meliputi belanja pegawai, belanja barang dan jasa serta belanja modal.

\subsubsection{Pengaruh Dana Alokasi Umum terhadap Anggaran Belanja Modal}

Variabel Dana Alokasi Umum berpengaruh positif, searah, serta berpengaruh secara signifikan terhadap jumlah anggaran belanja modal dengan tingkat signifikansi variabel independent $0.007<0,05$. Hal ini berarti bahwa pendapatan asli daerah berpengaruh terhadap anggaran belanja modal di Provinsi Sulawesi Utara. Hal ini didukung oleh hasil koefisien regresi sebesar positif 0,370 menandakan bahwa apabila dana alokasi umum di Provinsi Sulawesi Utara bertambah atau mengalami peningkatan sebesar Rp. 1, maka jumlah Anggaran Belanja Modal yang dialokasikan akan ikut bertambah atau mengalami kenaikan sebesar Rp. 0,370 dengan asumsi variabel lainnya tetap atau konstan. Hasil pengujian ini sejalan dengan hasil penelitian yang dilakukan oleh Anggiat Situngkir (2009) yang membuktikan bahwa besarnya jumlah belanja modal dipengaruhi oleh Dana Alokasi Umum yang diterima dari pemerintah pusat.

Transfer dari pemerintah pusat yang diwujudkan dalama dana alokasi umum untuk dana perimbangan merupakan sumber utama Pemda untuk menjaga/menjamin tercapainya standar pelayanan publik minimum di seluruh negeri. Transfer merupakan konsekuensi dari tidak meratanya kemampuan keuangan dan ekonomi daerah. Selain itu, tujuan transfer adalah mengurangi kesenjangan keuangan 
horizontal antar daerah, mengurangi kesenjangan vertical Pusat-Daerah, mengatasi persoalan efek pelayanan publik antar daerah, dan untuk menciptakan stabilitas aktifitas perekonomian di daerah. Di Indonesia, seperti ditegaskan dalam UU No. 25/1999, bentuk transfer yang paling penting adalah DAU dan DAK, selain bagi hasil (revenue sharing). Transfer atau grants dari Pemerintah Pusat secara garis besar dapat dibagi dua, yakni matching grant dan non-matching grants. Kedua grants tersebut digunakan oleh Pemda untuk memenuhi belanja rutin dan belanja pembangunan.

Perimbangan keuangan antaran pemerintah pusat dan daerah merupakan konsekuensi adanya penyerahan kewenangan pemerintah pusat kepada pemerintah daerah. Terjadinya transfer dana dari pemerintah pusat ke permintah daerah, maka pemerintah daerah secara leluasa dapat menggunakan dana untuk memberi pelayanan yang lebih baik kepada masyarakat. DAU merupakan salah satu alat bagi pemerintah pusat sebagai alat pemerataan pembangunan di Indonesia yang bertujuan untuk mengurangi ketimpangan dalam kebutuhan pembiayaan dan penguasaan pajak antara Pusat dan Daerah. Dengan perimbangan tersebut, khususnya dari DAU akan memberikan kepastian bagi Daerah dalam memperoleh sumber-sumber pembiayaan untuk membiayai kebutuhan pembangunan. Tujuan dari pemberian DAU ini adalah pemerataan dengan memperhatikan potensi daerah, luas daerah, keadaan geografis, jumlah penduduk, dan tingkat pendapatan.Jaminan keseimbangan penyelenggaran Pemerintah Daerah dalam rangka penyediaan pelayanan dasar kepada masyarakat. Oleh karena itu DAU merupakan sumber dana yang dominan dan dapat meningkatkan pelayanan kepada masyarakat.

\section{KESIMPULAN DAN SARAN \\ Kesimpulan}

Berdasarkan hasil pembahasan, maka dapat diambil kesimpulan sebagai berikut :

1. Pendapatan asli daerah berpengaruh secara signifikan terhadap anggaran belanja modal, sehingga pendapatan asli daerah merupakan sumber pendapatan penting bagi sebuah daerah dalam memenuhi belanjanya dan juga sekaligus dapat menunjukan tingkat kemandirian suatu daerah.

2. Dana alokasi umum berpengaruh secara signifikan terhadap anggaran belanja modal, sehingga dana alokasi umum merupakan salah satu alat bagi pemerintah pusat sebagai alat pemerataan pembangunan di Indonesia yang bertujuan untuk mengurangi ketimpangan dalam kebutuhan pembiayaan dan penguasaan pajak antara Pusat dan Daerah.

3. Pendapatan asli daerah dan dana alokasi umum secara simultan berpengaruh terhadap anggaran belanja modal di Provinsi Sulawesi Utara. Dan pengaruh ini di tinjau dari koefisien determinasi di peroleh sekitar $91,4 \%$ sedangkan sisanya sebesar 8,6\% dipengaruhi oleh faktor-faktor atau variabel

\section{Saran} lain yang tidak diteliti dalam penelitian ini.

Setelah melakukan dan melihat hasil dari penelitian ini, maka penulis dapat memberikan beberapa saran. Adapun saran-saran tersebut adalah sebagai berikut :

1. Pemerintah Provinsi Sulawesi Utara diharapkan perlu untuk memaksimalkan jumlah pendapatan asli daerah yang diperoleh dari berbagai unsur penerimaan daerah. Pemerintah Provinsi harus lebih giat lagi menggenjot sumber-sumber penerimaan daerah yang belum dioptimalkan sehingga bisa meningkatkan PAD.

2. Pengalokasian anggaran untuk belanja modal dari sektor dana alokasi umum (DAU) masih harus mendapat perhatian lebih dari Pemerintah Provinsi Sulawesi Utara, mengingat persentase peningkatan anggaran belanja modal yang bersumber dari dana alokasi umum masih sangat kecil bila dibandingkan dengan faktor-faktor pertumbuhan ekonomi lainnya.

\section{DAFTAR PUSTAKA}

Abdullah, Syukriy, 2004. Perilaku Oportunistik Legislatif dalam Penganggaran Daerah: Pendekatan Principal-Agent Theory. Makalah disajikan pada Seminar Antarbangsa di Universitas Bengkulu. Bengkulu. 4-5 Oktober 2004.

Anggiat Situngkir, 2009.Pengaruh Pertumbuhan Ekonomi, Pendapatan Asli Daerah, Dana Alokasi Umum, dan Dana Alokasi Khusus Terhadap Anggaran belanja Modal di Kabupaten/kota Sumatra Utara. Pasca Sarjana Universitas Sumatra Utara, Medan 
BAPPENAS. 2003. Peta Kemampuan Keuangan Provinsi dalam Era Otonomi Daerah : Tinjauan Atas Kinerja PAD dan Upaya yang dilakukan Daerah. Direktorat Jenderal Pengembangan Otonomi Daerah. Jakarta.

Bastian Indra, 2002. Sistem Akuntansi Sektor Publik, buku satu, salemba empat, Jakarta.

Departemen Keuangan RI. Kebijakan Desentralisasi Fiskal dan Pengelolaan Keuangan Daerah. 2009.

Halim, Abdul. 2001. Analisis Varian Atas Anggaran PAD pada Anggaran Pendapatan dan Belanja Daerah Kabupaten/Kota di Indonesia.

Halim, Abdul \& Syukriy Abdullah. 2004. Pengaruh Dana Alokasi Umum dan Pendapatan Asli Daerah Terhadap Belanja Pemda: Studi Kasus Kabupaten dan Kota di Jawa dan Bali. Jurnal Ekonomi STE.

Irma Syafitri, 2009.Pengaruh Pertumbuhan Ekonomi, Pendapatan Asli Daerah, dan Dana Alokasi Umum Terhadap Pengalokasian Anggaran belanja Modal di Kabupaten/kota Sumatra Utara. Universitas Sumatra Utara, Medan

Keputusan Menteri Dalam Negeri No. 29 Tahun 2002, tentang Pedoman Pengurusan, Pertanggungjawaban dan Pengawasan Keuangan Daerah Serta Tata Cara Penyusunan Anggaran Pendapatan dan Belanja Daerah, Pelaksaanaan tata Usaha Keuangan Daerah dan Penyusunan Perhitungan Anggaran Pendapatan dan Belanja Daerah.

Kuncoro, Mudrajad, 2004. Otonomi dan Pembangunan Daerah: Reformasi Perencanaan, Strategi dan Peluang. Penerbit Erlangga. Jakarta.

Peraturan Menteri Dalam Negeri nomor 13 tahun 2006 tentang Pedoman Pengelolaan Keuangan Daerah. Peraturan Pemerintah Nomor 55 Tahun 2005, tentang Dana Perimbangan atau Dana Alokasi Umum. Peraturan Pemerintah Nomor 56 Tahun 2005, tentang Sistem Informasi Keuangan Daerah.

Peraturan Pemerintah Nomor 58 Tahun 2005, tentang Pengelolaan Keuangan Daerah.

Prakosa, Kesit Bambang. 2004. Analisa Pengaruh DAU dan PAD terhadap Prediksi Belanja Daerah (Studi Empirik di Provinsi Jawa Tengah dan DIY) JAAI Vol. 8 N0. 2. 101-118.

Saragih, Juli panglima, 2003.Desentralisasi Fiskal dan Keuangan Daerah dalam otonomi.Penerbit Ghalia Indonesia, Jakarta

Sugiyono, 2004.Metode Penelitian Bisnis, Penerbit Alfabeta, Bandung.

Undang-Undang RI No. 22 tahun 1999 tentang Pemerintah Daerah.

No. 25 Tahun 1999 tentangPerimbangan Keuangan Pusat dan Daerah.

No. 32 Tahun 2004 tentangPemerintah Daerah.

No. 33 Tahun 2004 tentangPerimbangan Keuangan antara pemerintah pusat dan pemerintah daerah. Departemen Komunikasi dan Informatika. Jakarta.

No. 28 Tahun 2009 tentangPajak Daerah dan Retribusi Daerah. 